Stanisław PARZYMIES

Janusz SYMONIDES

Uniwersytet Warszawski

\title{
ROLA PRAWA MIĘDZYNARODOWEGO W ROZWOJU NAUKI O STOSUNKACH MIĘZYNARODOWYCH
}

Rola prawa międzynarodowego w rozwoju nauki o stosunkach międzynarodowych jest ogromna. Można wręcz powiedzieć, że prawo międzynarodowe realizując swe wielorakie funkcje przyczyniło się w znacznej mierze do tego, że stosunki międzynarodowe stały się samodzielną dyscypliną naukową, a przynajmniej, że za taką są uznawane w wielu krajach. Rozwój prawa międzynarodowego stanowi impuls dla rozwoju nauki o stosunkach międzynarodowych. Nauka o stosunkach międzynarodowych ma złożony charakter. Powstała z syntezy kilku dyscyplin. W badaniach nad stosunkami międzynarodowymi uwzględnia się zagadnienia historyczne, geograficzne, ekonomiczne, socjologiczne i oczywiście prawne. Przedmiot nauki o stosunkach międzynarodowych jest więc znacznie szerszy niż przedmiot nauki prawa międzynarodowego. Ale prawo międzynarodowe jest ważnym, jeśli nie najważniejszym komponentem tej nauki.

\section{MIEJSCE PRAWA MIĘDZYNARODOWEGO W TEORII STOSUNKÓW MIĘDZYNARODOWYCH}

Jedną z krytycznych uwag, jakie można sformułować pod adresem teorii stosunków międzynarodowych jest nieuwzględnianie, czy co najmniej niedocenianie znaczenia prawa międzynarodowego. „Mimo swej wszechobecności, prawo międzynarodowe przyciągnęło względnie małą uwagę ze strony badaczy stosunków międzynarodowych. Ale także, niezależnie od ścisłego związku między polityką i prawem, badacze prawa międzynarodowego przywiązują względnie małą uwagę do polityki międzynarodowej. Dochodzi powoli do zbliżenia między nimi, ale jest ono daleko niepełne" - pisze Michael Byres ${ }^{1}$. Wprawdzie od lat osiemdziesiątych XX wieku następuje rozwój teorii normatywnych w reakcji na teorie zwłaszcza neorealistyczne, jednak odwołuja się one nie tylko do norm prawnomiędzynarodowych, lecz również do norm etycznych, moralnych czy kurtuazyjnych. Nie ulega wattpliwości, że każdy porządek międzynarodowy musi mieć komponent normatywny. Uwzględnia on pewien system wartości obejmujący obecnie takie pojęcia jak wolność, sprawiedliwość, demokracja, prawa człowieka czy ochronę środowiska. Nie można jednak w ten sam sposób traktować

1 M. Byres, International Law, w: The Oxford Handbook of International Relations, eds. Ch. Reus-Smit, D. Snidal, Oxford University Press, Oxford 2010, s. 612. 
i sprowadzać do wspólnego mianownika z jednej strony norm etycznych, moralnych i kurtuazyjnych, z drugiej zaś norm prawa międzynarodowego. Przyczyna jest oczywista. Pierwsze nie są prawnie wiążące i nie prowadzą w przypadku ich naruszenia do odpowiedzialności, która może być dochodzona przed organami międzynarodowymi, podczas gdy normy prawa międzynarodowego są wiążące i mogą być podstawą wiążących orzeczeń sądów międzynarodowych, prowadzą do powstania nie tylko odpowiedzialności materialnej po stronie państwa, ale i do zastosowania sankcji karnych w stosunku do osób winnych popełnienia zbrodni międzynarodowych.

Ład międzynarodowy nie może istnieć bez norm prawa międzynarodowego, zarówno umownych, jak i zwyczajowych, które stanowią jego konstytutywny element. Jest to widoczne w przypadku często powoływanych w historii stosunków międzynarodowych ładów: westfalskiego, wiedeńskiego, wersalskiego czy jałtańsko-poczdamskiego. Wszystkie związane były z kongresami i konferencjami, na których doszło do przyjęcia ważnych porozumień i regulacji prawnomiędzynarodowych. Kiedy po I wojnie światowej powstawała nauka o stosunkach międzynarodowych, była ona zdominowana aż do lat trzydziestych przez liberalny internacjonalizm (wilsonism). Opierał się on na założeniu, że prawo międzynarodowe będzie przestrzegane przez państwa demokratyczne i umacniane przez rozwój wolnego handlu. Demokracja miała być gwarancją pokoju, zaś system bezpieczeństwa zbiorowego miał zastąpić porządek międzynarodowy oparty na istnieniu antagonistycznych sojuszy. Zrozumiałe jest zatem, że budowę ładu międzynarodowego wiązano z utworzeniem Ligi Narodów. Nadzieje na to, że ten ład będzie trwały okazały się jednak płonne.

Druga wojna światowa, a następnie początek zimnej wojny wzmocniły znaczenie realizmu w teorii stosunków międzynarodowych. Koncepcja interesu narodowego definiowanego jako władza, stała się obiektywną kategorią mającą powszechne zastosowanie. Wedle tej koncepcji polityka w stosunkach międzynarodowych, jak wszystkie polityki, jest walką o władzę. Stosunki międzynarodowe były postrzegane przez realistów przez pryzmat zdolności do wpływania i dominowania. Szkoła realistyczna, której głównym przedstawicielem był chicagowski profesor Hans Morgenthau, zwana była również kierunkiem polityki siły (Power politics ${ }^{2}$ ). Prowadziło to do kwestionowania w latach pięćdziesiątych i sześćdziesiątych roli prawa międzynarodowego, tym samym do kwestionowania poglądów zwolenników szkoły normatywistycznej. Miało to ogromny wpływ, zwłaszcza na Zachodzie, ale również w ZSRR, na naukę stosunków międzynarodowych, gdyż ograniczało w niej rolę prawa międzynarodowego na rzecz potęi rozumianej nie tylko jako siła fizyczna, ale szerzej jako władza człowieka nad umysłami i działalnością innych ludzi, jako instrument w rękach państwa w celu urzeczywistnienia „,interesu narodowego”.

Ponowne podkreślenie znaczenia prawa międzynarodowego $\mathrm{w}$ teorii stosunków międzynarodowych związane jest $\mathrm{z}$ pojawieniem się $\mathrm{w}$ latach siedemdziesiątych XX wieku tzw. szkoły angielskiej. W monografii poświęconej ,,anarchicznej społeczności” H. Bull, poddał krytyce amerykański realizm wskazując, że stosunki między państwami nie mogą być zredukowane tylko do analizy atrybutów władzy i modeli

2 J. Kukułka, Teoria stosunków międzynarodowych, Wydawnictwo Naukowe „Scholar”, Warszawa 2000, s. 95-96; oraz S. Sur, Relations internationales, Montchrestien, Paris 1995, s. 26-27. 
procesów decyzyjnych. Społeczność międzynarodowa, choć bez władzy centralnej, powiązana jest różnymi więzami, wśród których prawo międzynarodowe odgrywa wiodącą rolę. Państwa i inni uczestnicy stosunków międzynarodowych, jak argumentowali przedstawiciele szkoły angielskiej, są w stanie respektować przyjęte normy i zasady, nie z uwagi na solidarność czy przynależność do tej samej wspólnoty wartości, ale $\mathrm{z}$ uwagi na to, że $\mathrm{w}$ ich interesie leży przestrzeganie norm regulujących wzajemne stosunki ${ }^{3}$.

Teorią, która odnotowuje znaczenie regulacji międzynarodowych, zastępując prawo międzynarodowe innym terminem jest sformułowana w latach osiemdziesiątych teoria reżimów międzynarodowych. Wedle określenia S. Krasnera, reżimy to określone zasady, normy, reguły i procedury decyzyjne, wokół których zbiegają się oczekiwania aktorów w danej dziedzinie stosunków międzynarodowych ${ }^{4}$. Można zatem przyjaćć, że teoria reżimów jest próbą odpowiedzi na pytanie sformułowane przez neorealizm i neoliberalizm, jak współpraca może się rozwijać w sytuacjach, kiedy każdy aktor ma powody, by być egoistą. Teoria reżimów może być jednak krytykowana jako próba zastąpienia prawa międzynarodowego przez jego specyficznie interpretowane i dowolnie dobierane fragmenty.

Koniec zimnej wojny, fala demokratyzacji, transformacja ustrojowa w wielu krajach, zakończenie dysput ideologicznych i sporów wokół praw człowieka stworzyły nową jakościowo sytuację dla umacniania prawa międzynarodowego, które zaczęło być postrzegane także przez teoretyków stosunków międzynarodowych, jako istotny czynnik w coraz większym stopniu określający postępowanie państw. Doprowadziło to do wysunięcia nowej teorii „legitymizacji międzynarodowej”. Prawo międzynarodowe zgodnie z nią staje się elementem legitymizacji, czyli stwierdzenia zgodności postępowania państw $\mathrm{z}$ ich zobowiązaniami międzynarodowymi. Legitymizacji dokonują organizacje międzyrządowe: Narody Zjednoczone, organizacje wyspecjalizowane, organizacje regionalne $\mathrm{i}$ integracyjne, sądy międzynarodowe orzekające $\mathrm{w}$ sprawach spornych oraz poszczególne państwa. To są elementy twardej legitymizacji. Elementami miękkiej legitymizacji jest stanowisko organizacji pozarządowych i aktorów niepaństwowych oraz reakcja międzynarodowej opinii publicznej. Brak legitymizacji może, jak w przypadku Stanów Zjednoczonych w wojnie przeciwko terroryzmowi doprowadzić do zmian w polityce zagranicznej i wewnętrznej i do zmiany postępowania państw.

\section{NIE NA NAUKI O STOSUNKACH MIĘDZYNARODOWYCH BEZ PRAWA MIĘDZYNARODOWEGO}

Prawo międzynarodowe regulując stosunki międzynarodowe w coraz większej liczbie dziedzin poszerza obszary badań stosunków międzynarodowych (prawo dyplomatyczne, prawo humanitarne, prawo do samostanowienia, prawo rozbrojenia, prawo

3 H. Bull, The Anarchical Society, McMilan, London 1971.

4 S. Krasner, Structural causes and regime consequences: regimes as intervening variables, w: International Regimes, ed. S. Krasner, Cornel University Press, Ithaca-New York 1983, s. 2. 
przeciwwojenne, prawo ochrony środowiska, prawo praw człowieka). To od podstaw normatywnych stosunków międzynarodowych zaczynamy na ogół badanie i analizę tych stosunków.

W sensie formalnym zmiany w prawie międzynarodowym mogą być wprowadzone za pośrednictwem umów międzynarodowych. Nowe porozumienia zastępują czy zmieniają dotychczasowe. Modyfikacje mogą także wynikać z postępowania państw (praktyki międzynarodowej), które zostaje uznane za prawnie obowiązujące. Dochodzi w ten sposób do wykształcenia się normy zwyczajowej. Zmiana niekoniecznie oznacza odejście od obowiązujących norm czy zasad prawa międzynarodowego, lecz jest również rezultatem przyjęcia ich odmiennej interpretacji. Widać to choćby w przypadku zasad: suwerenności, nieinterwencji w sprawy wewnętrzne, kompetencji wewnętrznej czy samostanowienia.

Nie każda modyfikacja czy zastąpienie istniejącej normy ma jednakowe znaczenie i zasługuje na taką samą uwagę. Należy pamiętać, że prawo międzynarodowe obejmuje nie tylko normy powszechnie obowiązujące erga omnes, które mogą mieć charakter również norm bezwzględnie obowiązujących, ale także normy partykularne obowiązujące inter partes, ustanawiane przez tysiące umów resortowych, które nie są ratyfikowane czy zatwierdzane i w konsekwencji nie maja priorytetu nad ustawami poszczególnych państw.

Stosunki międzynarodowe i prawo międzynarodowe są ze sobą ściśle powiązane i zależne. Stosunki międzynarodowe powinny zatem być realizowane w integralnym związku i z uwzględnieniem ich normatywnej podstawy. Bez uwzględnienia prawa międzynarodowego nauka o stosunkach międzynarodowych jest ułomna i nie może w pełni objaśnić podstawowej kwestii, dlaczego państwa, organizacje międzynarodowe i inne podmioty postępują w określony sposób, co wpływa na procesy decyzyjne, jak interesy poszczególnych aktorów i kompromisy znajdują swoją artykulację w przyjmowanych regulacjach. Z kolei prawo międzynarodowe bez uwzględnienia stosunków międzynarodowych staje się dyscypliną dogmatyczną, oderwaną od rzeczywistości i nie będącą w stanie objaśnić materialnych źródeł norm, zasad i instytucji międzynarodowych. Stosunki międzynarodowe są glebą, z której wyrastają normy prawa międzynarodowego. Uwzględnienie tego ścisłego związku może tylko wzbogacać obie dyscypliny tak w warstwie teoretycznej, jak i praktycznej.

Ewolucja prawa międzynarodowego przyczyniła się do ucywilizowania stosunków między państwami Zachodu i państwami strefy pozaeuropejskiej, dawnymi koloniami, poprzez odrzucenie obowiązującego jeszcze do I wojny światowej w klasycznym prawie międzynarodowym podziału na narody cywilizowane i niecywilizowane, poprzez odrzucenie zasady nierówności traktatów jako zgodnej z prawem międzynarodowym, w sumie do zmiany przekonania, o czym pisał algierski prawnik, były sędzia MTS, Mohammed Bedjaoui we wstępie do wydanego w 1991 r. przez UNESCO zbiorowego podręcznika Prawo międzynarodowe, że prawo międzynarodowe ma charakter europejski, chrześcijański, merkantylistyczny i imperialistyczny ${ }^{5}$.

5 M. Bedjaoui, Introduction générale, w: Droit international. Bilan et perspectives, t. 1, réd. général M. Bedjaoui, UNESCO, 1991, s. 6. 
Prawo międzynarodowe i nauka prawa międzynarodowego znacznie wyprzedziły powstanie nauki o stosunkach międzynarodowych jako samodzielnej dyscypliny, o której możemy mówić dopiero po I wojnie światowej. Stosunki międzynarodowe istniały oczywiście wcześniej niż prawo je regulujące, ale nauka o tych stosunkach ściśle wiązała się z pojawieniem się prawa międzynarodowego. Rozprawy o wojnie sprawiedliwej św. Augustyna i św. Tomasza z Akwinu ${ }^{6}$, czy Pawła Włodkowica i Stanisława ze Skarbimierza, rozprawy o prawie dyplomatycznym Bernarda du Rosier (1436 r. - Ambaxiator brevilogus) i Krzysztofa Warszewickigo (1595 r. - De legato et legationis), Sześć ksiag o Republice Jeana Bodin, gdzie jako pierwszy zdefiniował suwerenność i nazwał zasadę pacta sunt servanda, czy rozprawy Hugo Grocjusza o wolności mórz oraz o wojnie i pokoju, są na to dowodem.

Prawo międzynarodowe jest punktem odniesienia dla oceny zachowania państw w środowisku międzynarodowym, stanowiąc ochronę dla państw średnich i małych przed arogancją wielkich mocarstw, czego wyrazem jest np. zakaz użycia siły, zasada nieingerencji, obowiązek pokojowego załatwiania sporów. Określa konkretne, zindywidualizowane formy stosunków między państwami, takie jak sojusze, neutralność, współpraca gospodarcza. Zawiera powszechne regulacje dotyczące wzajemnych stosunków między państwami w formie prawa dyplomatycznego i prawa konsularnego. Reguluje kwestie zasięgu władzy terytorialnej, dotyczące granic, ich delimitacji, nienaruszalności, integralności terytorialnej. Ustala reguły postępowania na obszarach niepodlegających niczyjej suwerenności, a więc na morzu pełnym czy w przestrzeni kosmicznej. Określa podstawowe zasady, na których opiera się współpraca państw, takie jak suwerenna równość państw, prawo narodów do samostanowienia, wypełnianie w dobrej wierze zobowiązań międzynarodowych.

Zawsze, szczególnie po konfliktach zbrojnych, kiedy wynikiem konferencji międzynarodowych było ustanowienie nowego ładu normatywnego lub tylko przypomnienie już istniejących norm w celu podkreślenia ich znaczenia, prawo międzynarodowe stanowiło inspirację, stymulację i ukierunkowanie dla rozwoju nauki o stosunkach międzynarodowych. Kongresowi Wiedeńskiemu z 1815 r. zawdzięczamy pierwszą kodyfikację prawa dyplomatycznego i uznanie wolności żeglugi na rzekach wspólnych. Konferencje haskie z 1899 i 1907 r. przyniosły kodyfikację prawa wojennego i prawa dotyczącego pokojowego załatwiania sporów międzynarodowych. Efektem Konferencji Pokojowej w Wersalu w 1919 r. był Pakt Ligi Narodów, pierwszej organizacji bezpieczeństwa zbiorowego. Konferencja w San Francisco zakończyła się w czerwcu 1945 r. uchwaleniem Karty Narodów Zjednoczonych, kolejnej, istniejącej dotychczas organizacji bezpieczeństwa zbiorowego. W 1948 r. Zgromadzenie Ogólne Narodów Zjednoczonych wypracowało i przyjęło Powszechną Deklarację Praw Człowieka. Wielkim osiagnięciem Rady Europy było przyjęcie w 1950 r. Konwencji o ochronie praw człowieka i podstawowych wolności.

W Traktacie paryskim z 1951 r. i traktatach rzymskich z 1957 r. określone zostały normy regulujące warunki współpracy państw w procesie integracji europejskiej. Konferencja w Bandungu 24 krajów Azji i Afryki uchwaliła w 1955 r. deklarację 10 zasad

${ }^{6}$ R. Coste, Théologie de la paix, Paris 1997, s. 138-151. 
pokojowego współistnienia, dające początek aktywnemu włączeniu się do stosunków międzynarodowych państw Trzeciego Świata. Wielkie znaczenie w procesie demokratyzowania stosunków międzynarodowych miały uchwalona przez Zgromadzenie Ogólne ONZ w 1970 r. Deklaracja zasad prawa międzynarodowego i uchwalona w 1974 r. Karta Praw i Obowiązków Ekonomicznych Państw. Duży wkład w nasycenie stosunków międzynarodowych normami prawa międzynarodowego miała Konferencja Bezpieczeństwa i Współpracy w Europie, zamieszczając w swoim $A k$ cie Końcowym z 1975 r., dekalog zasad wzajemnych stosunków państw, czy uchwalając na spotkaniu w Paryżu w listopadzie 1990 r. Paryską Kartę Nowej Europy. Wreszcie nie można nie docenić modelowego dla innych regionów wkładu w rozwój stosunków międzynarodowych, jaki stanowią normy prawa międzynarodowego zawarte w traktatach o Unii Europejskiej z Maastricht, Amsterdamu, Nicei i Lizbony.

\section{EWOLUCJA PRAWA MIĘDZYNARODOWEGO I JEJ WPLYW NA NAUKE O STOSUNKACH MIĘDZYNARODOWYCH W ŚWIECIE POZIMNOWOJENNYM}

Co dzisiaj prawo międzynarodowe wnosi do nauki o stosunkach międzynarodowych, czym inspiruje i stymuluje rozwój tej nauki, jaki ma wpływ na ład międzynarodowy, a tym samym na rozwój nauki o stosunkach międzynarodowych?

Koniec zimnej wojny, fala demokratyzacji, transformacja ustrojowa w wielu krajach, zakończenie dysput ideologicznych i sporów wokół praw człowieka stworzyły nową jakościowo sytuację dla umacniania prawa międzynarodowego, które zaczęło być postrzegane także przez teoretyków stosunków międzynarodowych, jako istotny czynnik w coraz większym stopniu określający postępowanie państw. W wielu ważnych dokumentach międzynarodowych mówi się wręcz o rządach prawa w stosunkach międzynarodowych, jak w Deklaracji Milenijnej Narodów Zjednoczonych z 2000 r., w Dokumencie Końcowym Szczytu Światowego z 2005 r., czy w Warszawskiej Deklaracji szczytu Rady Europy z 2005 r.

Głównym problemem jest to, że istniejący ład odzwierciedla świat z końca II wojny światowej, a nie świat, który istnieje obecnie. Dzisiejsze zagrożenia i wyzwania są inne, współzależność znacznie większa, układ sił i rzeczywistość geopolityczna radykalnie odmienna. Stąd też ład ten wymaga daleko idącej transformacji i reformy oraz uwzględnienia nowego układu sił i włączenia w procesy decyzyjne nowych i wyłaniających się mocarstw. W wymiarze regionalnym, ład międzynarodowy, skuteczny i pełnowymiarowy jest już tworzony przez Unię Europejską. Rozwiązania i regulacje, które w układzie globalnym mogą być traktowane jako odległe, czy wręcz niemożliwe do osiagnięcia, w odniesieniu do państw i obszaru unijnego już funkcjonują. Przestrzeń wolności, bezpieczeństwa i sprawiedliwości jest nie tylko zamierzeniem teoretycznym, lecz rzeczywistością.

Czy model europejski ma szansę na upowszechnienie i przyjęcie go przez inne regiony, a tym samym na doprowadzenie do stworzenia ładu światowego opartego na ładach regionalnych? Jest to realna perspektywa, gdyż ewolucja i przyjęcie modelu eu- 
ropejskiego jest proklamowanym celem, obejmującej 53 państwa Unii Afrykańskiej i 10 państw Stowarzyszenia Narodów Azji Południowo-Wschodniej (ASEAN), a o działaniu na rzecz tworzenia integracji ekonomicznej i unii monetarnej mówią także kraje Unii Krajów Południowej Ameryki (14 państw), kraje Rady Współpracy Zatoki (6 państw) oraz 21 państw APEC (Wspólnota Gospodarcza Azji i Pacyfiku).

Na przełomie XX i XXI wieku w stosunkach międzynarodowych nastapiły ważne wydarzenia i ujawniły się procesy, które nie mogły pozostać bez następstw dla prawa międzynarodowego. Niewątpliwie na pierwszym miejscu wśród nich należy wymienić zakończenie ,zimnej wojny”. Następnie rozpad Związku Radzieckiego i upadek reżimów totalitarnych w różnych częściach świata spowodowały, że na znaczeniu zyskały dwa fundamentalne dla rozwoju prawa międzynarodowego procesy: demokratyzacja i umocnienie praw człowieka. Przez świat przetaczała się fala demokratyzacji i transformacji prowadząca do umocnienia pozycji jednostki w stosunku do państwa, czego wyrazem stała się możliwość występowania przez jednostki przed trybunałami międzynarodowymi przeciwko własnemu państwu.

Wśród wielu innych procesów oddziaływujących na państwa obok demokratyzacji czy modernizacji, dwa zasługują na szczególną uwagę: proces globalizacji oraz proces integracji. Oba prowadzą bowiem do przekazywania kompetencji państwowych podmiotom niepaństwowym, odpowiednio - organizacjom integracyjnym i korporacjom wielonarodowym. Oba w istotny sposób zmieniają też sposoby funkcjonowania państw. Globalizacja i integracja prowadzą także, jak się to czasem określa, do utraty przez terytorium ,nieprzenikliwości” czy do ,deterytorializacji” państwa. Swobodny przepływ osób, towarów, kapitałów i usług na obszarze Unii Europejskiej czy porozumienia z Schengen umacniają to przekonanie. Państwa, mimo występujących między nimi różnic, zgodziły się na ograniczenie wykonywania swoich praw suwerennych na rzecz Unii Europejskiej. Rozwiązania te przyjęły nie tylko małe i średnie kraje europejskie, lecz także największe, łącznie ze stałymi członkami Rady Bezpieczeństwa - Francją i Wielką Brytanią.

Wzrasta znaczenie sądownictwa międzynarodowego. Podnoszone w czasie ,zimnej wojny", głównie przez państwa rozwijające się i bloku wschodniego, zastrzeżenia wobec Międzynarodowego Trybunału Sprawiedliwości doprowadziły do kryzysu sądownictwa międzynarodowego. Choć wciąż daleko jest do powszechnego przyjęcia obowiązkowej jurysdykcji MTS, to postęp staje się widoczny. W 2007 r. nieco więcej niż trzecia część członków ONZ, bo 66 państw, złożyło deklarację o przyjęciu obowiązkowej jurysdykcji MTS. Polska uczyniła to pierwszy raz 25 września 1990 r. oraz ponownie w zmodyfikowanej wersji - 25 marca 1996 r. Klauzulę sądową zawiera około 300 obowiązujących obecnie umów wielostronnych i dwustronnych ${ }^{7}$.

Tendencja do umacniania roli sądownictwa międzynarodowego widoczna jest także w tworzeniu nowych trybunałów. Konwencja o prawie morza z 1982 r. weszła w życie 16 listopada 1994 r. Jej część XV poświęcona jest załatwianiu sporów, które mogą powstać w związku z jej interpretacją i stosowaniem. Art. 279 nakłada na strony obowiązek załatwienia sporów środkami pokojowymi zgodnie z Kartą Narodów Zjednoczonych.

\footnotetext{
${ }^{7}$ Report of the International Court of Justice, 1 August 2010-31 July 2011, s. 3.
} 
Na przełomie XX i XXI w. nastapił istotny postęp we wprowadzaniu w życie odpowiedzialności karnej za zbrodnie międzynarodowe. Próby jej ustanowienia sięgają pierwszej wojny światowej. Po zakończeniu drugiej wojny światowej cztery zwycięskie mocarstwa - Francja, Stany Zjednoczone, Wielka Brytania i ZSRR - działając w imieniu Narodów Zjednoczonych, utworzyły 8 sierpnia 1945 r. Międzynarodowy Trybunał Wojskowy do osądzenia głównych przestępców wojennych w Europie, których czyny nie były związane z określonym obszarem geograficznym.

Idea powołania do życia międzynarodowego trybunału karnego została sformułowana w art. VI Konwencji w sprawie zapobiegania i karania zbrodni ludobójstwa, który stanowi: „Osoby oskarżone o ludobójstwo [...] będą sądzone przez właściwy trybunał państwa, na którego obszarze czyn został dokonany, lub przez międzynarodowy trybunał karny". Przez wiele lat nie podejmowano jednak żadnych działań zmierzających do utworzenia takiego trybunału. Przełom nastąpił w latach dziewięćdziesiątych XX w. W roku 1993 Rada Bezpieczeństwa ONZ, działając na podstawie rozdziału VII Karty NZ, utworzyła. Międzynarodowy Trybunał dla byłej Jugosławii z siedzibą w Hadze. Rok później, w związku z aktami ludobójstwa w Rwandzie, Rada Bezpieczeństwa utworzyła Międzynarodowy Trybunał dla Rwandy z siedzibą w Aruszy w Tanzanii. W 2002 r. ONZ i Sierra Leone podpisały porozumienie ustanawiające Specjalny Trybunał dla Sierra Leone. We wszystkich trzech trybunałach sądzono osoby, które ponoszą odpowiedzialność za zbrodnie międzynarodowe popełnione w tych krajach.

Negocjacje zmierzające do wypracowania Statutu Międzynarodowego Trybunału Karnego (MTK) rozpoczęły się w 1995 r. na podstawie projektu przygotowanego i przyjętego przez Komisję Prawa Międzynarodowego w lipcu 1994 r. W 1995 r. powołano Komitet Przygotowawczy dla opracowania projektu Statutu w celu przedstawienia go na konferencji dyplomatycznej zwołanej dla jego przyjęcia, które ostatecznie nastapiło w lipcu 1995 roku w Rzymie. Wejście w życie statutu MTK i rozpoczęcie działalności nie oznacza jednak, że wszystkie problemy i wątpliwości związane z funkcjonowaniem trybunału zostały już rozwiązane, a jego pełna skuteczność osiągnięta. Trudno twierdzić, by ze 120 ratyfikacjami statut mógł być uznany za umowę posiadającą w pełni uniwersalny charakter. Jeśli się zauważy, że Narody Zjednoczone mają obecnie 193 członków, to wskazana liczba ratyfikacji, mimo wzrastającej tendencji, oznacza, iż w istocie nieco mniej niż dwie trzecie członków ONZ związanych jest postanowieniami statutu. Co więcej, zaniepokojenie może wywoływać fakt, że z pięciu stałych członków Rady Bezpieczeństwa tylko Francja i Wielka Brytania są stronami statutu, ChRL i Rosja nawet go nie podpisały, a Stany Zjednoczone w oświadczeniu z 6 maja 2002 r. poinformowały Sekretarza generalnego ONZ, że nie zamierzają zostać jego stroną. Tymczasem akceptacja przez wszystkich stałych członków Rady Bezpieczeństwa Statutu MTK miałaby istotne znaczenie.

Skuteczność Międzynarodowego Trybunału Karnego stanęła pod znakiem zapytania w związku z działaniami Stanów Zjednoczonych zmierzających do wyłączenia spod jego jurysdykcji, poprzez umowy dwustronne, obywateli amerykańskich oraz zakwestionowania zasadności jego utworzenia. Dążenie to doprowadziło do konfrontacji między USA a Unią Europejską. Wszystkie państwa członkowskie Unii Europejskiej 
są stronami Statutu MTK, stąd też stoi ona na stanowisku, że nie można się godzić z działaniami, które dążą do ,zrujnowania i sabotowania MTK i zakwestionowania prymatu prawa na arenie międzynarodowej" ${ }^{\prime}$. Administracja prezydenta B. Obamy, co należy z satysfakcją odnotować, zrezygnowała z ataków na Międzynarodowy Trybunał Karny.

Ważnym wyzwaniem dla społeczności międzynarodowej jest walka z terroryzmem. W ciągu czterdziestu lat (1969-2009) w systemie ONZ przyjęto trzynaście konwencji międzynarodowych w sprawie zwalczania terroryzmu. Walka z terroryzmem musi być prowadzona, co wielokrotnie podkreślała Rada Bezpieczeństwa, Zgromadzenie Ogólne ONZ i organizacje regionalne z poszanowaniem prawa międzynarodowego. Wydarzenia z 11 września 2001 r., które uznano za atak na demokrację i społeczność międzynarodową, sprawiły, że w centrum uwagi świata znalazło się zwalczanie terroryzmu. Stąd też społeczność międzynarodowa zdecydowanie i jednoznacznie solidaryzowała się ze Stanami Zjednoczonymi, co znalazło wyraz w rezolucjach Zgromadzenia Ogólnego (56/1) i Rady Bezpieczeństwa (1368/2001) ONZ.

Ataki terrorystyczne stanowiły punkt zwrotny w polityce zagranicznej Stanów Zjednoczonych, który doprowadził do zmiany jej priorytetów. Czy jednak uzasadniały tezę o początku nowej ery w stosunkach międzynarodowych, o potrzebie tworzenia nowego ładu międzynarodowego opartego na nieograniczonym użyciu siły militarnej i aktach jednostronnych? Interwencja wojskowa Stanów Zjednoczonych i Wielkiej Brytanii w Iraku - z naruszeniem Karty NZ, bez decyzji Rady Bezpieczeństwa ONZ i pod fałszywym pretekstem - podzieliła społeczność międzynarodową. W znacznej mierze kontrowersje dotyczyły fundamentalnej dla istniejącego obecnie systemu bezpieczeństwa ONZ kwestii, czy zakaz groźby i użycia siły oraz prawo do indywidualnej i zbiorowej obrony mogą być zastapione koncepcją wojny i obrony prewencyjnej, czy zatem państwa mają prawo do samoobrony niezależnie od tego, czy miał miejsce atak zbrojny. Krytyce poddano próby zmiany obowiązującego obecnie zakazu groźby i użycia siły sformułowanego w art. 2, punkt 4 Karty Narodów Zjednoczonych i usankcjonowania wyprzedzającego (prewencyjnego) użycia siły, co znalazło swój wyraz w sprzecznym z prawem międzynarodowym ataku USA na Irak ${ }^{10}$.

Społeczność międzynarodowa w dokumencie końcowym przyjętym przez Zgromadzenie Ogólne w 2005 r. odrzuciła koncepcję wyprzedzającego użycia siły w walce $\mathrm{z}$ terroryzmem. Walka z terrorystycznymi aktorami transnarodowymi wpisuje się zatem albo w konflikt zbrojny i jest regulowana przez istniejące normy, albo w sytuacji,

8 Partie de bras de fer USA-UE autour de la Cour pénale internationale, „Le Figaro”, 12.06.2003; Cl. Tréan, La guerelle entre les Etats-Unis et l'Europe sur la Cour pénale internationale rebondit, „Le Monde”, 16.06.2003; B. Knowiton, Th. Fuller, After War, a New Rift between U.S. and EU, „International Herald Tribune”, 11.06. 2003.

${ }_{9}$ R. Kuźniar, Niebezpieczeństwa nowego paradygmatu bezpieczeństwa, w: Bezpieczeństwo międzynarodowe czasu przemian. Zagrożenia - koncepcje - instytucje. Księga pamiatkowa A. D. Rotfel$d a$, red. R. Kuźniar, Z. Lachowski, Polski Instytut Spraw Międzynarodowych, Warszawa 2003, s. 229.

10 Por. szerzej na ten temat: J. Symonides, Wojna z Irakiem a prawo międzynarodowe, „Rocznik Strategiczny" 2003/2004, Warszawa 2004, s. 366 i n. 
gdy działania terrorystów nie osiagną pułapu konfliktu międzynarodowego czy wewnętrznego i sprowadzają się do wewnętrznych zamieszek czy sporadycznych aktów terrorystycznych, stosują się do niej inne normy prawa międzynarodowego i prawa krajowego. Sprawcy mogą być pociągnięci do odpowiedzialności przed sądami krajów, w których doszło do tych aktów (terroryści, którzy dokonali zamachów w Londynie, Madrycie czy na Bali zostali postawieni przed sądami krajowymi i skazani na podstawie prawa karnego poszczególnych państw), mogą odpowiadać w ramach jurysdykcji uniwersalnej czy przed Międzynarodowym Trybunałem Karnym. Walka z terroryzmem musi być prowadzona, co wielokrotnie podkreślała Rada Bezpieczeństwa, Zgromadzenie Ogólne ONZ i organizacje regionalne z poszanowaniem prawa międzynarodowego, międzynarodowego prawa humanitarnego, prawa uchodźców i międzynarodowego prawa praw człowieka, a także prawa krajowego.

Czy to oznacza, że nie ma żadnej potrzeby uściślenia pewnych zasad współpracy $\mathrm{w}$ walce $\mathrm{z}$ terroryzmem międzynarodowym? Wprawdzie nie ma uzasadnienia dla opracowania nowego protokołu dodatkowego do konwencji genewskich z 1949 r. dotyczącego konfliktów transnarodowych, jednak w dalszym ciagu istnieje potrzeba przyjęcia uzgodnionej definicji terroryzmu i całościowej konwencji. Można zastanawiać się także nad słusznością ewentualnego wyodrębnienia zbrodni terroryzmu w statucie Międzynarodowego Trybunału Karnego. Można też postulować wzmocnienie systemu bezpieczeństwa zbiorowego ONZ poprzez przyjęcie kryteriów użycia siły militarnej w sytuacjach zagrożenia czy naruszenia pokoju i bezpieczeństwa międzynarodowego przez planowane czy przeprowadzane zamachy terrorystyczne. Słuszna więc wydaje się teza, że istniejące prawo międzynarodowe zawiera wystarczające normy dla prowadzenia skutecznej walki z terroryzmem międzynarodowym, tak na poziomie globalnym, regionalnym, jak i krajowym, zarówno w czasie konfliktów zbrojnych, jak i w czasie pokoju.

Próba przekonania społeczności międzynarodowej, że w „wojnie z terroryzmem” prowadzonej w słusznej sprawie, w obronie demokracji i praw człowieka z okrutnym i nieprzestrzegającym norm prawa międzynarodowego przeciwnikiem można odejść od ich przestrzegania została odrzucona. Przyjęcie takiego stanowiska oznaczałoby $\mathrm{w}$ istocie sukces terrorystów, pogrzebanie i kompromitację szczytnych ideałów, którymi winny kierować się państwa demokratyczne, przestrzegające praw człowieka i praworządne. Powszechne kwestionowanie samego terminu ,wojna z terroryzmem", tej jak to określano - semantycznej, strategicznej i prawnej perwersji - doprowadziło ostatecznie do rezygnacji z niej przez administrację prezydenta Baracka Obamy.

Relatywnie wzrasta znaczenie aktorów niepaństwowych oraz proces ich upodmiotowienia $\mathrm{w}$ prawie międzynarodowym. Trend prowadzący do zwiększenia $\mathrm{w}$ prawie międzynarodowym miejsca i znaczenia aktorów niepaństwowych, stanowienia norm bezpośrednio adresowanych do nich oraz poszerzenia ich zdolności działania w stosunkach międzynarodowych z pewnością będzie w XXI wieku przybierał na sile, jest bowiem zgodny z ogólnym kierunkiem rozwoju społeczności międzynarodowej. Wśród aktorów niepaństwowych odgrywających coraz większą rolę w stosunkach międzynarodowych pierwsze miejsce zajmują organizacje pozarządowe działające $\mathrm{w}$ sferze praw człowieka, ochrony środowiska, pomocy humanitarnej, utrzymania pokoju, 
współpracy naukowej, kulturalnej oraz w wielu innych dziedzinach ${ }^{11}$. W ciągu ostatnich lat znaczenie organizacji pozarządowych stale wzrasta. Są ważnym partnerem systemu Narodów Zjednoczonych. Jak przewiduje art. 71 Karty NZ, Rada Gospodarcza i Społeczna ONZ może podjąć odpowiednie działania w celu konsultacji z organizacjami pozarządowymi w zakresie ich kompetencji. Od początku lat dziewięćdziesiątych obserwuje się - nie występujące wcześniej w takiej skali - szerokie uczestnictwo organizacji pozarządowych w konferencjach światowych zwoływanych przez Narody Zjednoczone. Akredytacje organizacji w czasie tych konferencji wykraczają daleko poza status konsultacyjny przyznawany przez Radę Gospodarczą i Społeczną.

Organizacje pozarządowe biorą udział w przygotowywaniu przez system Narodów Zjednoczonych i organizacje regionalne standardów międzynarodowych. Wpływają na działalność normatywną, popierając ,wpisanie” określonych tematów do porządku dziennego prac organów międzynarodowych, uczestnicząc bezpośrednio w przygotowywaniu projektów, w konferencjach, grupach roboczych i dyskusyjnych oraz konsultacjach ekspertów, a także proponując poprawki. W niektórych przypadkach organizacje pozarządowe zapoczątkowały prace nad projektami umów międzynarodowych. Ich ważna pozycja w promocji i ochronie praw człowieka, ochronie środowiska naturalnego, zapobieganiu konfliktom międzynarodowym oraz podejmowaniu różnorodnych problemów ludzkości została powszechnie uznana przez społeczność międzynarodową. System Narodów Zjednoczonych współpracuje z organizacjami pozarządowymi na nowych, bardziej elastycznych, partnerskich zasadach. Relacje między rządami a organizacjami pozarządowymi nie są pozbawione napięć z uwagi na to, że rosnąca świadomość społeczna i monitorowanie postępowania władz prowadzą często do krytyki poszczególnych państw i mobilizowania światowej opinii publicznej w razie naruszenia prawa międzynarodowego. Można uznać, że postęp prawa międzynarodowego i jego przestrzeganie zależą w znacznej mierze od działań tych organizacji i od tworzącego się obecnie globalnego społeczeństwa obywatelskiego.

W dobie globalizacji coraz większą rolę w stosunkach międzynarodowych odgrywają korporacje transnarodowe, przy czym ich znaczenie rośnie w miarę upływu cza$\mathrm{su}^{12}$. Można mówić o istnieniu swoistego sprzężenia zwrotnego. Globalizacja tworzy im nowe możliwości ekspansji i działania, to zaś prowadzi z kolei do wzmacniania i pogłębiania procesów globalizacji. Z tego powodu korporacje określane są często jako jej główni aktorzy czy beneficjenci ${ }^{13}$. Największe korporacyjne giganty „upodabniaja”, się do państw i wykazuja pewną zdolność do działań na płaszczyźnie międzynarodowej. Zawierają bowiem umowy, które choć nie mają formalnie charakteru umów międzynarodowych, dla wielu krajów są ważniejsze niż porozumienia z innymi państwami

11 Por.: P. Archer, Action by Unofficial Organizations on Human Rights, w: The International Protection of Human Rights, ed. E. Luard, Thames and Hudson, London 1967, s. 160-182; J. Symonides, M. Symonides, Wktad organizacji pozarzqdowych w promocję i ochronę praw człowieka, „Stosunki Międzynarodowe/International Relations" 2004, nr 1-2, s. 9-24.

12 T. de Montbrial, Działania i system świata, Wydawnictwo Akademickie Dialog, Warszawa 2010, s. 214-215.

${ }_{13}$ J. Baylis, S. Smith, The Globalization of the World Politics: An Introduction to International Relations, Oxford University Press, New York 2001, s. 357. 
czy organizacjami międzynarodowymi. Niektóre posiadają zagraniczne placówki czy reprezentację w wielu państwach. Nierzadko używają własnej flagi czy bandery. Mają wreszcie pewne możliwości odwoływania się do sądownictwa bądź arbitrażu międzynarodowego.

Kompetencja państw do szczegółowego nadzoru, regulacji i podporząakowania korporacji, które mają przynależność danego państwa, jest w znacznej mierze teoretyczna i to z kilku względów. Państwa macierzyste są z reguły zainteresowane wspieraniem ekspansji i rozwojem korporacji. Towarzyszy temu tendencja deregulacyjna, czyli dążenie do odejścia od sztywnych regulacji zasad ich funkcjonowania. Z kolei kraje goszczące filie i oddziały pragną tworzyć najlepsze warunki do przyciągania inwestycji zagranicznych. Korporacje rejestrują się także w „rajach podatkowych”, które programowo rezygnują ze sprawowania jakiegokolwiek nadzoru i kontroli.

Presja deregulacyjna i niechęć państw do jednostronnego określania warunków funkcjonowania korporacji transnarodowych i ich obowiązków oznaczają że możliwe jest wypracowanie określonych standardów międzynarodowych, jednakowych dla wszystkich korporacji. Działania takie, podejmowane przez ONZ, Organizację Współpracy Gospodarczej i Rozwoju, Międzynarodową Organizację Pracy, Międzynarodowy Bank Odbudowy i Rozwoju, Międzynarodowy Fundusz Walutowy, Unię Europejską, Radę Europy i Organizację Państw Amerykańskich, zmierzają zwłaszcza do zwalczania międzynarodowej korupcji oraz przestrzegania zasad uczciwej konkurencji.

Na przełomie XX i XXI wieku szczególnego znaczenia nabrała kwestia odpowiedzialności społecznej korporacji wielonarodowych. W latach dziewięćdziesiątych ubiegłego stulecia organizacje pozarządowe podjęły działania na rzecz wymuszenia na korporacjach przestrzegania praw człowieka, zwalczania pracy przymusowej, pracy dzieci oraz respektowania praw pracowniczych i ochrony środowiska. Konieczność zaakceptowania odpowiedzialności społecznej została uznana przez znaczną część korporacji.

Obok aktorów międzynarodowych kontrolowanych czy pozostających w sferze oddziaływania państwa, są tacy, którzy pozostaja poza obszarem jego kompetencji. W tym drugim przypadku dotyczy to struktur i organizacji terrorystycznych czy zorganizowanej międzynarodowej przestępczości, które, korzystając z nowych możliwości związanych z procesami globalizacji ekonomicznej i informatycznej do tradycyjnych obszarów swojej działalności, jak handel ludźmi, przemyt narkotyków, broni czy pranie brudnych pieniędzy, dodają coraz to nowe obszary działalności, jak przykładowo związane z nośnikami energii czy handlem organami ludzkimi.

Umacnianie się zasady poszanowania praw człowieka oraz zasad demokracji i praworządności prowadzi do postępującego upodmiotowienia jednostki. Wprawdzie instrumenty dotyczące praw człowieka zostały przyjęte wcześniej, jednak dopiero w ostatnich latach nastapiło umocnienie procedur kontrolnych oraz systemów ochrony praw człowieka - zarówno powszechnego Narodów Zjednoczonych, jak i regionalnych w Europie, Ameryce i Afryce. Osoby fizyczne uzyskały dostęp do wielu procedur petycyjnych i mogą występować przed Europejskim Trybunałem Sprawiedliwości, Europejskim Trybunałem Praw Człowieka czy Międzynarodowym Trybunałem Prawa Morza. Przestrzeganie międzynarodowych praw człowieka zostało wyłączone z kompetencji wewnętrznej państw i stało się przedmiotem debaty międzynarodowej. 
W coraz szerszym zakresie prawo międzynarodowe dostrzega miejsce i rolę jednostki w stosunkach międzynarodowych (prawo azylu, międzynarodowa ochrona praw człowieka, ochrona praw osób należących do mniejszości, odpowiedzialność za ochronę). Prawo międzynarodowe nie tylko poszerza zakres przysługujących jednostce praw, ale i ustanawia jej międzynarodową odpowiedzialność karną za zbrodnie międzynarodowe. Jednocześnie proces umacniania praw człowieka i pozycji jednostki jest widoczny w wielu organizacjach regionalnych (Rada Europy, Unia Europejska). Otworzyło to nowe możliwości pociagania do odpowiedzialności przed sądami krajowymi za zbrodnie międzynarodowe, niezależnie od obywatelstwa sprawcy i miejsca ich popełnienia. W ślad za Belgią, która w 1993 r. przyjęła zasadę represji realizowanej erga omnes - w skali światowej - podobne zasady postępowania przyjęło wiele innych państw.

Proces umacniania praw człowieka i pozycji jednostki jest widoczny w wielu organizacjach regionalnych, zwłaszcza europejskich, takich jak Rada Europy. Po zakończeniu „zimnej wojny” został dodany do celów i kierunków działalności Unii Europejskiej. Uznanie poszanowania praw człowieka za wartość, na której opiera się Unia, oraz cel jej działania, a także przyznanie Karcie Praw Podstawowych wiążącego, traktatowego charakteru oznacza zakończenie pewnego etapu ewolucji, który doprowadził do zaakceptowania nadrzędnej roli osoby ludzkiej, jej nienaruszalności i niezbywalnych praw.

Ewolucji podlega pojęcie suwerenności. Nie ulega wątpliwości, że suwerenność w swym obecnym kształcie różni się znacznie od rozumienia tego pojęcia, kiedy powstawał system westfalski (1648 r.) oparty na istnieniu i akceptacji całkowicie niezależnych państw. Przede wszystkim rozwój prawa międzynarodowego oznacza, że państwa poprzez umowy i zwyczaj międzynarodowy przyjęły system norm regulujących ich postępowanie i ograniczyły w ten sposób wykonywanie swoich praw suwerennych. Kompetencja wewnętrzna uległa i ulega w dalszym ciągu zawężeniu. Pojęcie nieingerencji w sprawy wewnętrzne w świetle międzynarodowej ochrony praw człowieka, praw mniejszości czy ludności autochtonicznej jest redefiniowane. Każda niemal umowa międzynarodowa niesie jej ograniczenie.

Znalazło to swój wyraz w przyjętej w dokumencie końcowym 60. Sesji Zgromadzenia Ogólnego ONZ zasadzie odpowiedzialności za ochronę ludności przed ludobójstwem, zbrodniami wojennymi, czystkami etnicznymi i zbrodniami przeciwko ludzkości. Ta wynikająca z suwerenności odpowiedzialność spoczywa na państwach, które zobowiązane są do ochrony własnej ludności, a jeśli tego nie czynią, to członkowie ONZ są „gotowi do podjęcia za pośrednictwem Rady Bezpieczeństwa kolektywnego, w odpowiednim czasie i w zdecydowany sposób”, działania. Oznacza to zgodę państw członkowskich na odwołanie się do sankcji przewidzianych w artykułach 42 i 43 rozdziału VII Karty NZ. Odpowiedzialność za ochronę obejmuje jej trzy rodzaje, a właściwie stadia: zapobieganie (prewencję), działanie (reagowanie) i odbudowę. W pierwszym przypadku odpowiedzialność polega na ostrzeganiu, a także usuwaniu źródeł i przyczyn wewnętrznych konfliktów oraz powodowanych przez człowieka katastrof i kryzysów. Drugi rodzaj odpowiedzialności odnosi się do działań mających na celu reagowanie (odpowiedź) na ludzkie potrzeby właściwymi środkami, np. przymusu, takimi jak sankcje i odpowiedzialność karna, a w ekstremalnych sytuacjach także interwencja wojskowa. Trzeci oznacza zapewnienie niezbędnej pomocy w odbudowie 
i pojednaniu, zwłaszcza po interwencji militarnej, oraz eliminowanie przyczyn kryzysów i szkód. Najważniejszym rodzajem odpowiedzialności za ochronę jest prewencja, której możliwości powinny być w pełni wyczerpane przed odwołaniem się do interwencji.

Suwerenność stanowi podstawę odpowiedzialności państwa za ochronę jego ludności. Kiedy jednak ludność ponosi poważne szkody w rezultacie wojen (konfliktów) wewnętrznych, powstań, represji czy upadku państwa, a suweren, na którego terytorium ma to miejsce, nie chce lub nie jest w stanie zapobiec tej sytuacji bądź jej zmienić, zasada nieinterwencji ustępuje miejsca międzynarodowej odpowiedzialności za ochronę. Zasada odpowiedzialności za ochronę została ostatecznie przyjęta w dokumencie końcowym 60. sesji Zgromadzenia Ogólnego ONZ ${ }^{14}$. Stwierdza się w nim jednoznacznie, że chodzi o odpowiedzialność za ochronę ludności przed ludobójstwem, zbrodniami wojennymi, czystkami etnicznymi i zbrodniami przeciwko ludzkości. Odpowiedzialność ta spoczywa na państwach, które zobowiązane są do ochrony własnej ludności, w czym powinna im pomagać społeczność międzynarodowa, sięgając po odpowiednie dyplomatyczne, humanitarne i inne środki pokojowe zgodnie z rozdziałami VI i VIII Karty Narodów Zjednoczonych. Gdy środki pokojowe okażą się nieadekwatne, a władze krajowe w oczywisty sposób nie będą chronić swojej ludności, członkowie ONZ są „gotowi do podjęcia za pośrednictwem Rady Bezpieczeństwa kolektywnego działania, w odpowiednim czasie i w zdecydowany sposób" ${ }^{\text {"15 }}$. Oznacza to zgodę państw członkowskich na odwołanie się do interwencji militarnej zgodnie z art. 42 i 43 Karty NZ. Jednomyślne przyjęcie $\mathrm{w}$ czasie jubileuszowej 60. sesji Zgromadzenia Ogólnego, w której uczestniczyło 150 szefów państw i rządów, zasady odpowiedzialności za ochronę ludności przed ludobójstwem, zbrodniami wojennymi, czystkami etnicznymi i zbrodniami przeciwko ludzkości należy uznać za jedno z największych osiągnięć dotyczących praw człowieka i bezpieczeństwa międzynarodowego w procesie reformowania Organizacji Narodów Zjednoczonych. Oznacza to też przełom w podejściu koncepcyjnym. Dokument końcowy jubileuszowej sesji ONZ wyznaczył kierunek dalszego rozwoju prawa międzynarodowego.

Jakkolwiek w stosunkach międzynarodowych zwiększa się również udział uczestników subpaństwowych, jak: regiony, stany, kantony, terytoria stowarzyszone czy autonomiczne, które będą intensyfikować swoje bezpośrednie relacje transgraniczne i reprezentować swoje interesy w stosunkach $\mathrm{z}$ organizacjami międzynarodowymi, to jednak państwo w dalszym ciągu ponosi główną odpowiedzialność za realizację ekonomicznych, społecznych i kulturalnych praw człowieka, za przestrzeganie praw mniejszości i ludności tubylczej. Czy zostanie ono zastapione przez inne podmioty? Na to pytanie należy odpowiedzieć negatywnie. Nie jest to realna perspektywa. Wprawdzie państwo będzie podlegać dalszej ewolucji i nieuchronnej transformacji, jednak nie zostanie ono „zdetronizowane" i zastapione przez innych uczestników obrotu międzynarodowego ${ }^{16}$.

${ }^{14}$ Responsibility to Protect Populations from Genocide, War Crimes, Ethnic Cleansing and Crimes against Humanity, World Summit Outcome Document, 24 October 2005. Doc. A/Res/60/1.

15 Ibidem.

16 J. Symonides, Wplyw globalizacji na miejsce i rolę państwa w stosunkach międzynarodowych, w: Globalizacja a stosunki międzynarodowe, red. E. Haliżak, R. Kuźniar, J. Symonides, Oficyna Wydawnicza BRANTA, Bydgoszcz-Warszawa 2003. 
Zasadniczym elementem tego nowego kształtującego się porządku międzynarodowego, mimo ogromnego wzrostu liczby aktorów i ich wielopłaszczyznowych relacji i oddziaływania na system międzynarodowy, pozostaną nadal państwa. Ani Narody Zjednoczone nie zostaną przekształcone w rząd światowy, ani Unia Europejska i inne struktury regionalne nie przekształcą się w federację i nie pozbawią suwerenności swoich członków. Również korporacje transnarodowe nie „ubezwłasnowolnią” państw i nie przejmą ich wszystkich kompetencji. Oddziałujące na państwa procesy globalizacji, integracji i demokratyzacji, praw człowieka czy praworządności będą jednak prowadzić do ich dalszej transformacji i ewolucji, do dostosowywania się do nowych wyzwań i zagrożeń. Efekty tych oddziaływań i niektórych interakcji są i z pewnością będą różne także w przyszłości. Jedne państwa będą rosnąć w siłę i uzyskiwać mocarstwowy status, inne będą słabnąć, a jeszcze inne nawet staną wobec perspektywy „upadku czy bankructwa”. Nie oznacza to jednak zakwestionowania tezy, że państwo nadal pozostanie podstawowym i głównym uczestnikiem stosunków międzynarodowych, tym bardziej, że nie ma „kandydata” do jego zastąpienia.

Presja na państwo, a także decentralizacja, deregulacja i prywatyzacja prowadzą do istotnych przeobrażeń w sprawowaniu zwierzchnictwa terytorialnego i personalnego. Następuje, jak to się czasem określa, utrata „nieprzenikliwości” czy „deterytorializacja” państwa oraz wyraźnie zmienia się sposób traktowania własnych i obcych obywateli. Globalizacja nie powoduje jednak i nie przyspiesza zapowiadanego od kilkudziesięciu lat kryzysu, zmierzchu czy implozji państwa. Nie prowadzi też do utraty przez nie suwerenności, choć stawia je wobec nowych wymagań i wyzwań. Globalizacja, co się wydaje pewnym paradoksem, wymaga istnienia państwa. Bez wątpienia wolny rynek nie może przejąć funkcji regulacyjnych i wykonywać ich w jego zastępstwie. Państwo musi zatem dalej działać jako superarbiter, regulator i gwarant rządów prawa.

System Narodów Zjednoczonych powinien być zreformowany w stopniu zapewniającym większą możliwość efektywnego działania na rzecz utrzymania pokoju i bezpieczeństwa międzynarodowego, rozwoju, poszanowania praw człowieka, zasad demokracji i przestrzegania prawa międzynarodowego. Zależeć to będzie jednak od układu sił. Oznacza to konieczność poszerzenia Rady Bezpieczeństwa i przyjęcia nowych zasad jej funkcjonowania. Przebudowa ładu ekonomicznego, przezwyciężenie kryzysu finansowego, energetycznego, przyjęcie innych regulacji międzynarodowych stosunków gospodarczych będzie wymagać współpracy wszystkich międzynarodowych organizacji gospodarczych: Banku Światowego, Funduszu Walutowego, Światowej Organizacji Handlu oraz organizacji integracyjnych.

\section{KIERUNKI DALSZYCH ZMIAN LADU NORMATYWNEGO W STOSUNKACH MIĘDZYNARODOWYCH}

Kontrowersje występujące między krajami, odmienne priorytety i interesy powodują, że nie udaje się uzgodnić wielu podstawowych norm prawnomiędzynarodowych. Nie ma powszechnie obowiązującej definicji terroryzmu międzynarodowego, agresji, mniejszości czy ludów tubylczych. Nie ustalono kryteriów użycia siły militarnej. Tylko kilka umów międzynarodowych, takich jak Karta Narodów Zjednoczonych, Konwen- 
cja praw dziecka, czy konwencje genewskie z 1949 r., przyjęła cała społeczność międzynarodowa.

Czy możliwe jest przezwyciężenie istniejących podziałów i sprzeczności? Na pytanie to należy udzielić odpowiedzi twierdzącej. Świadczą o tym rezultaty negocjacji dotyczących reformowania ONZ. Przyjęty przez światowy szczyt na 60. sesji Zgromadzenia Ogólnego dokument końcowy jest co prawda rezolucja, ale o szczególnym znaczeniu. Stanowi bowiem wynik długotrwałych negocjacji i ich podsumowanie, może zatem uchodzić za wyraz opinii całej społeczności międzynarodowej. Postanowienia dotyczące samej organizacji, jej organów czy zasad funkcjonowania mogą być uznane za wiążące. Dokument końcowy potwierdził więc możliwość osiagania kompromisu i dalszego rozwoju prawa międzynarodowego. W dokumencie końcowym jednoznacznie potwierdzono dalsze obowiązywanie postanowień Karty Narodów Zjednoczonych w kwestiach użycia siły i prawa do samoobrony, i to bez żadnych zmian, a także wymóg przestrzegania praw człowieka i prawa humanitarnego w walce $\mathrm{z}$ terroryzmem międzynarodowym.

Czy występowanie wielu negatywnych czynników oznacza, że normatywna podstawa ładu międzynarodowego się załamuje, a świat staje wobec nieuchronnej perspektywy pogrążenia się w anarchii i chaosie? Nic nie uzasadnia takiej tezy. Przeciwnie, znaczenie prawa międzynarodowego nie tylko nie maleje, lecz wzrasta, jakkolwiek jest to proces złożony i powolniejszy, niż oczekuje tego społeczność międzynarodowa. Słabości i naruszenia reguł międzynarodowych wiążą się obecnie głównie z nielegalnym użyciem siły militarnej oraz nierespektowaniem prawa humanitarnego i praw człowieka w konfliktach zbrojnych, a także w kontekście walki z terroryzmem międzynarodowym. Jest to jednak udziałem tylko ograniczonej liczby państw. Pozostałe normy prawa międzynarodowego są na ogół powszechnie przestrzegane: prawo dyplomatyczne i konsularne, prawo morza, prawo lotnicze czy kosmiczne, również normy o charakterze technicznym i ponadczasowym dotyczące współpracy gospodarczej, kulturalnej, granicznej czy sądowej. Pozytywnie należy ocenić fakt, że w wyniku procesu demokratyzacji i transformacji ustrojowej do konstytucji wielu państw wpisano zobowiązanie do przestrzegania prawa międzynarodowego oraz uznanie wyższości ratyfikowanych i ogłoszonych umów nad pozostającymi z nimi w kolizji ustawami.

Czy można wskazać jeden kierunek dalszej ewolucji prawa międzynarodowego w XXI wieku? Bez wątpienia wspólnym mianownikiem jest ochrona godności ludzkiej i interesów uniwersalnej społeczności, czyli ludzkości. Suwerenność i zasada nieinterwencji w sprawy wewnętrzne nie mogą chronić dziś winnych zbrodni międzynarodowych. Rola aktorów niepaństwowych i ich wpływ na rozwój i umacnianie prawa międzynarodowego są oczywiste. Konieczność prawnomiędzynarodowej regulacji ich działań i odpowiedzialności społecznej oraz bezpośredniego adresowania do nich zobowiązań wobec społeczności międzynarodowej nie budzi już dziś wątpliwości ${ }^{17}$.

Pojęcie społeczności i prawa międzynarodowego wymaga w XXI wieku redefinicji. Społeczność międzynarodowa obejmuje już nie tylko państwa i organizacje międzynarodowe, lecz także organizacje pozarządowe, korporacje transnarodowe i jednostki.

17 J. Symonides, Prawo międzynarodowe: kierunki zmian, w: Dokad zmierza świat?, red. A. D. Rotfeld, Polski Instytut Spraw Międzynarodowych, Warszawa 2008, s. 43-66. 
Prawo międzynarodowe reguluje stosunki nie tylko między państwami i organizacjami międzynarodowymi, ale także między nimi i aktorami niepaństwowymi. Ci ostatni nie oznaczają jednak ,implozji” czy zastąpienia państwa, lecz jego współistnienie z innymi aktorami. Transformacja systemu wartości wyznacza demokratycznym państwom i społeczności międzynarodowej zorganizowanej w Narodach Zjednoczonych nowe zadania zapewnienia rozwoju, bezpieczeństwa, praw człowieka i demokracji każdej jednostce. Właśnie w tym kierunku, mimo wszystkich utrudnień i oporów, będzie się rozwijać prawo międzynarodowe.

Istnieje konieczność dostosowania porządku międzynarodowego do wyzwań i zagrożeń XXI wieku. Nie ulega wątpliwości konieczność dostosowania całej architektury bezpieczeństwa międzynarodowego stworzonej przez rozdział VII Karty NZ do nowych wyzwań, zwiększenia efektywności Rady Bezpieczeństwa i jej powiększenia, jak też wzmocnienia i uzupełnienia efektywnymi sankcjami istniejącego reżimu nierozprzestrzeniania broni masowego rażenia.

Ład międzynarodowy w pierwszej dekadzie obecnego stulecia znalazł się i jak to już wcześniej odnotowaliśmy pod wpływem sprzecznych tendencji i działań prowadzonych równocześnie do jego osłabienia, kwestionowania czy erozji, z drugiej zaś do jego konsolidacji i umacniania ${ }^{18}$. Zagrożeń i wyzwań jest wiele. Dotyczą one bezpieczeństwa międzynarodowego, co wiąże się z proliferacją broni masowego rażenia oraz wyścigiem zbrojeń konwencjonalnych i terroryzmem międzynarodowym, a także rosnącą liczbą konfliktów, zwłaszcza wewnętrznych. Są one następstwem zjawisk kryzysowych w międzynarodowych stosunkach ekonomicznych, wynikających z braku równomiernego rozwoju, niesprawiedliwych warunków wymiany handlowej, kryzysów energetycznego i żywnościowego. Stanowią konsekwencję masowych naruszeń godności i praw człowieka, głodu oraz chorób. Godzą jak w przypadku zmian klimatycznych i zanieczyszczeń środowiska, w warunki życia człowieka. Wynikają ze wzrostu patologii międzynarodowych, postępu naukowo-technicznego, kryzysu wartości, a także zagrożeń regionalnych.

Najpoważniejszym obecnie źródłem zagrożeń ładu międzynarodowego są nie tyle, czy przede wszystkim, działania najpotężniejszych państw, co raczej aktorów niepaństwowych: globalnych organizacji terrorystycznych, ,,panów wojny”, nielegalnych milicji i struktur podporządkowanych zorganizowanej przestępczości. Godzą one w ład państwowy i międzynarodowy, naruszają prawa człowieka, zasady demokracji i praworządności, osłabiają państwa, a w skrajnych przypadkach prowadzą do ich upadku. Wojna $\mathrm{z}$ terroryzmem i koncepcja neokonserwatyzmu doprowadziły do kwestionowania międzynarodowego prawa humanitarnego i praw człowieka, do ataku na MTK, ONZ, do działań jednostronnych i użycia siły militarnej wbrew postanowieniom Karty Narodów Zjednoczonych.

Transnarodowy, globalny charakter tych zagrożeń powoduje, że odpowiedź na nie musi także być globalna. Zwalczanie terroryzmu wymaga ścisłej i skutecznej

18 Por. na ten temat: L. Pastusiak, Nowy ład światowy, w: Współczesne stosunki międzynarodowe, Akademia Finansów, Warszawa 2008, s. 105 i n.; W. Malendowski, Nowy ład międzynarodowy, w: Stosunki międzynarodowe, red. W. Malendowski, Cz. Mojsiewicz, Wrocław 2004, s. 44 i n.; J. Gilas, Prawo międzynarodowe, Comer, Torun 1995, s. 25 i n. 
współpracy państw i organizacji międzynarodowych. Interwencje w Afganistanie i Iraku dobitnie pokazały ograniczoną skuteczność użycia siły militarnej. Niezbędną staje się konsolidacja systemu uniwersalnych wartości. Należy tu wymienić zasadę solidarności międzynarodowej, zrównoważonego rozwoju, zasadę przezorności, bezpieczeństwa człowieka, czy koncepcję odpowiedzialności międzynarodowej za ochronę ludności. Rządy państw demokratycznych, nawet najpotężniejszych, muszą brać pod uwagę poglądy i oceny własnego społeczeństwa i międzynarodowej opinii publicznej. Organizacje pozarządowe z powodzeniem wymuszają na państwach zmiany, widoczne choćby w odniesieniu do kary śmierci, respektowania praw kobiet, praw mniejszości czy ludności tubylczej.

Znaczenie prawa międzynarodowego jako regulatora współczesnych stosunków między państwami wynika wreszcie z faktu, że współpraca, kompromisy i porozumienie, a więc umowa międzynarodowa, są niezbędne dla podjęcia wszystkich twardych i miękkich wyzwań oraz zagrożeń, przed jakimi stoi społeczność międzynarodowa. $\mathrm{Na}$ prawo międzynarodowe oddziałują też procesy regionalizacji, w szczególności Unia Europejska. Można postawić tezę, że staje się ona, niezależnie od kierowanej czasem pod jej adresem krytyki, istotnym czynnikiem respektowania prawa międzynarodowego. Model integracji europejskiej jest coraz bardziej atrakcyjny dla innych regionów.

Kryzys finansowy i recesja pierwszej dekady XXI wieku doprowadziły do istotnej weryfikacji neoliberalnych poglądów na rolę i miejsce państwa w gospodarce. Okazało się, że teza o samoregulacji wolnego rynku jest nieprawdziwa, a ingerencja państwa - niezbędna, by ratować podmioty gospodarcze zagrożone bankructwem. Państwa zatrzymały tendencje prywatyzacyjne i przystapiły w istocie do częściowej renacjonalizacji instytucji finansowych, do udzielenia wsparcia przedsiębiorstwom, zwłaszcza bankom zagrożonym upadkiem, do podejmowania wielorakich działań mających na celu zwiększenie możliwości kredytowych i siły nabywczej społeczeństw oraz ograniczenia bezrobocia przez realizacje programów robót publicznych. The State is back, państwo wróciło, to slogan, który charakteryzuje dzisiaj rolę państwa w stosunkach międzynarodowych, w warunkach kryzysu gospodarczego, z którym boryka się społeczność międzynarodowa.

Czy możliwe jest przezwyciężenie istniejących podziałów i sprzeczności? Na pytanie to należy udzielić odpowiedzi twierdzącej. Świadczą o tym rezultaty negocjacji dotyczących reformowania ONZ ${ }^{19}$. Czy można wskazać jeden kierunek dalszej ewolucji prawa międzynarodowego w XXI wieku? Bez wątpienia wspólnym mianownikiem jest ochrona godności ludzkiej i interesów uniwersalnej społeczności - ludzkości. Ład westfalski się przeżył ${ }^{20}$, suwerenność i zasada nieinterwencji w sprawy wewnętrzne nie mogą chronić dziś winnych zbrodni międzynarodowych, a społeczność międzynarodowa odpowiedzialna jest za ochronę i przyjście z pomocą zagrożonej ludności oraz

19 Szerzej na ten temat: A. D. Rotfeld, Przyszłość ONZ: ciagłość i zmiana, w: Organizacja Narodów Zjednoczonych. Bilans i perspektywy, red. J. Symonides, Wydawnictwo Naukowe Scholar, Warszawa 2006, s. 754 i n.

20 A. Makarewicz, Bezpieczeństwo człowieka oraz solidarność międzynarodowa: cel i podstawa nowego ładu międzynarodowego, w: Organizacja Narodów Zjednoczonych. Bilans i perspektywy, op. cit., s. $741 \mathrm{i} \mathrm{n.}$ 
wspieranie wysiłków budowania pokoju po konflikcie. Rola aktorów niepaństwowych i ich wpływ na rozwój i umacnianie prawa międzynarodowego są oczywiste. Konieczność prawnomiędzynarodowej regulacji ich działań i odpowiedzialności społecznej oraz bezpośredniego adresowania do nich zobowiązań wobec społeczności międzynarodowej nie budzi już dziś wątpliwości.

\section{POJĘCIE SPOLECZNOŚCI I PRAWA MIĘDZYNARODOWEGO WYMAGA W XXI WIEKU REDEFINICJI ${ }^{21}$}

Społeczność międzynarodowa obejmuje już nie tylko państwa i organizacje międzynarodowe, lecz także organizacje pozarządowe, korporacje transnarodowe i jednostki. Prawo międzynarodowe reguluje stosunki nie tylko między państwami i organizacjami międzynarodowymi, ale także między nimi i aktorami niepaństwowymi. Zmieniająca się obecnie społeczność międzynarodowa i zmieniający się ład międzynarodowy muszą jednak uwzględniać elementy kontynuacji, nie oznaczają zatem ,implozji” czy zastapienia państwa, lecz jego współistnienie z innymi aktorami. Transformacja systemu wartości wyznacza demokratycznym państwom i społeczności międzynarodowej zorganizowanej w Narodach Zjednoczonych nowe zadania zapewnienia rozwoju, bezpieczeństwa, praw człowieka i demokracji każdej jednostce. Właśnie w tym kierunku, mimo wszystkich utrudnień i oporów, będzie się rozwijać prawo międzynarodowe. Perspektywy dla prawa międzynarodowego są więc optymistyczne, gdyż rośnie jego znaczenie w stosunkach międzynarodowych, co otwiera nowe perspektywy dla nauki o stosunkach międzynarodowych.

Jakie są szanse konsolidacji i reformy istniejącego ładu, jego dostosowania do wyzwań i zagrożeń XXI wieku? Teza, że postęp jest niemożliwy, że nie da się przezwyciężyć ograniczeń wynikających z rozbieżności i sprzecznych interesów między państwami, niechęci mocarstw do poddawania się regulacjom międzynarodowym prowadzącym do ograniczenia wykonywania ich praw suwerennych, jak się wydaje, została zakwestionowana przez postęp, jaki we wprowadzaniu porządku regionalnego osiągnęła Unia Europejska ${ }^{22}$. Rozwiązania i regulacje, które w układzie globalnym mogą być traktowane jako cele odległe czy wręcz niemożliwe do osiagnięcia, w odniesieniu do państw i obszaru unijnego już funkcjonują. Przestrzeń wolności, bezpieczeństwa i sprawiedliwości ${ }^{23}$ jest nie tylko zamierzeniem teoretycznym, lecz rzeczywistością. Unia Europejska nie tylko wspiera pokój, ale z uwagi na powstanie wspólnoty bezpie-

21 A. Cassese (International Law, Oxford University Press, Oxford 2004, s. 18) wskazuje, że w prawie międzynarodowym funkcjonują dwa modele: jeden tradycyjny związany z Grocjuszem i drugi współczesny związany z Kantem. Pierwszy opiera się na podkreślaniu roli państwa realizującego swoje interesy w stosunkach międzynarodowych, drugi zaś - uniwersalny, kosmopolityczny - odwołuje się do potencjalnej wspólnoty ludzkości.

22 Kwestie te analizuje: S. Parzymies, Unia Europejska wobec wyzwań i zagrożeń w stosunkach międzynarodowych, w: Świat wobec współczesnych wyzwań i zagrożeń, red. J. Symonides, Wydawnictwo Naukowe SCHOLAR, Warszawa 2010, s. 609-636.

23 Por.: tytuł V, Traktat ofunkcjonowaniu Unii Europejskiej, w: Prawo Unii Europejskiej. Wybór dokumentów, Instytut Wydawniczy EuroPrawo, Warszawa 2009, s. 85-98. 
czeństwa, wyłączyła możliwości użycia siły między państwami członkowskimi. Decyzje podejmowane przez instytucje unijne są wiążące, a prawo przez nią stanowione jest częścią prawa wewnętrznego. System rozstrzygania sporów dostępny dla obywateli jest obowiązkowy, a orzeczenia są respektowane. Przestrzeganie zobowiązań jest kontrolowane, a sankcje są skuteczne. Państwa, mimo występujących między nimi różnic, zgodziły się na ograniczenie wykonywania swoich praw suwerennych na rzecz Unii, która w kilku dziedzinach ma kompetencje wyłączne. Rozwiązania te przyjęły nie tylko małe i średnie państwa europejskie, ale także największe łącznie ze stałymi członkami Rady Bezpieczeństwa - Francją i Wielką Brytanią. Istnieje realna perspektywa, że model europejski zostanie upowszechniony i przyjęty przez inne regiony, a tym samym dojdzie do stworzenia ładu światowego opartego na ładach regionalnych.

Jakie są możliwości i drogi reformowania obecnego ładu globalnego? Pozostawiając na uboczu nierealistyczne koncepcje stworzenia rządu światowego czy federacji światowej można odnotować, że istnieje szansa oraz możliwość reformowania i tworzenia rozwiązań dotyczących poszczególnych obszarów współpracy międzynarodowej. Nowe regulacje i formy współpracy są już wdrażane w życie, choćby decyzjami G-20. Podobnie tylko kwestią czasu wydaje się przyjęcie umowy regulującej współpracę państw w ograniczaniu emisji gazów cieplarnianych wraz z niezbędnymi dla tego celu rozwiązaniami instytucjonalnymi. W tym kontekście nie należy zapominać o propozycji francuskiej stworzenia nowej organizacji wyspecjalizowanej, która skuteczniej niż UNEP mogłaby się zajmować ochroną środowiska i zmianami klimatycznymi.

Jeśli chodzi o konieczność wypełnienia istniejących luk w prawie międzynarodowym to jak się wydaje istnieje potrzeba przyjęcia regulacji dotyczących działalności korporacji transnarodowych w szczególności zaś związanej z przejmowaniem funkcji państwowych w sferze bezpieczeństwa. Tworzenie prywatnych i najemnych sił policyjnych i wojskowych prowadzi do powstawania, jak świadczą o tym choćby działania Blackwater w Iraku, poważnych problemów z respektowaniem prawa humanitarnego i odpowiedzialnością. Niezbędny jest także dalszy rozwój międzynarodowego prawa karnego $^{24}$.

Reforma systemu Narodów Zjednoczonych musi także być kontynuowana. Dotyczy to zwłaszcza Rady Bezpieczeństwa i zasad funkcjonowania systemu bezpieczeństwa zbiorowego. Uznając za całkowicie nierealne propozycje stworzenia sił zbrojnych Narodów Zjednoczonych, za możliwe do realizacji należy przyjęcie kryteriów użycia siły militarnej przez RB w ramach rozdziału VII ${ }^{25}$. Bardziej ambitnym, ale i niezbędnym jest przyjęcie przez Narody Zjednoczone zasad postępowania i udzielania pomocy państwom słabym, upadającym i upadłym. Jak świadczy o tym choćby przykład Haiti, większość z nich, poza sytuacjami dramatycznych katastrof naturalnych, jest pozostawiona samym sobie i znajduje się poza obszarem zainteresowania Komisji Budowania

${ }^{24}$ Ostatnim przykładem wiązanych z międzynarodowym sądownictwem karnym są propozycje utworzenia specjalnego trybunału ONZ dla osądzania aktów piractwa. Patrz: Peace Palace Library, Call for an UN Piracy Tribunal, http://peacepalacelibrary-weekly.blogspot.com/2009/05/call-for-un-piracy.

${ }^{5}$ Wśród kryteriów, które należałoby brać pod uwagę przy podejmowaniu decyzji o użyciu siły militarnej zasadniczymi są: a) stopień i skala zagrożenia; b) cel; c) nieskuteczność środków pokojowych; d) proporcjonalność; e) szanse sukcesu. 
Pokoju ze wszystkimi tego faktu negatywnymi konsekwencjami dla społeczności międzynarodowej. Narody Zjednoczone nie mają także żadnej procedury i zasad postępowania w sytuacjach związanych z realizacją prawa narodów do samostanowienia, co także prowadzić może do konfliktów wewnętrznych i aktów terroryzmu.

Budowa całościowego, globalnego ładu, opartego na regulacjach międzynarodowych, współpracy i współdziałania całej społeczności nie jest zadaniem łatwym, jest jednak koniecznością z uwagi na zagrożenia globalne, którym nawet najsilniejsze państwa nie mogą i nie podołają w pojedynkę. Elementem pozytywnym niezależnie od niezadowalających ciagle rezultatów jest deklarowana gotowość wszystkich aktorów, nie tylko państw i organizacji międzynarodowych, lecz również organizacji pozarządowych i biznesu do współdziałania.

Wszystko to stawia społeczność międzynarodową wobec konieczności dokonania przebudowy porządku międzynarodowego. Niezbędną staje się konsolidacja systemu uniwersalnych wartości, przyjęcia nowych zasad oraz nowych koncepcji. Należy tu wymienić zasadę solidarności międzynarodowej, zrównoważonego rozwoju, zasadę przezorności, bezpieczeństwa człowieka, czy koncepcję odpowiedzialności międzynarodowej za ochronę ludności. System międzynarodowy, Narody Zjednoczone, organizacje regionalne i integracyjne wymagają niezbędnych inicjatyw, by człowiek i jego potrzeby stanęły w centrum ich działalności. Transformacja zglobalizowanych państw wymaga przyjęcia nowych regulacji międzynarodowych bezpośrednio adresowanych do aktorów niepaństwowych. Warunkiem skuteczności działań zmierzających do sprostania potrzebom XXI wieku jest umacnianie prawa międzynarodowego, reforma systemu Narodów Zjednoczonych, przyjęcie jurysdykcji międzynarodowych trybunałów oraz powszechna akceptacja odpowiedzialności międzynarodowej za zbrodnie międzynarodowe.

\section{STRESZCZENIE}

Stosunki międzynarodowe jako samodzielna dyscyplina naukowa zrodziły się z prawa międzynarodowego. W teorii stosunków międzynarodowych słusznie zwracano uwagę, że normy prawne nie są w stanie całkowicie określać postępowania państw, że wpływa na nie wiele innych czynników: siła, interesy, wartości... Jednak krytyka ta idzie zbyt daleko, prowadząc do niedoceniania czy wręcz kwestionowania znaczenia prawa międzynarodowego dla stosunków międzynarodowych. Żaden bowiem porządek międzynarodowy nie może istnieć bez norm prawa międzynarodowego. Koniec zimnej wojny stworzył nową jakościowo sytuację dla jego umacniania. Dochodzi do istotnej ewolucji i rozwoju prawa międzynarodowego. Jesteśmy świadkami postępującego upodmiotowienia jednostki. Ewolucji podlega pojęcie suwerenności. Zasada nieinterwencji ustępuje miejsca odpowiedzialności państwa za ochronę jego ludności. Sprawcy zbrodni międzynarodowych w wyniku rozwoju sądownictwa międzynarodowego pociaggani są do odpowiedzialności karnej. Kończy się era bezkarności za naruszanie norm prawa międzynarodowego. Pojęcie społeczności i podmiotowość wymaga jednak w XXI wieku redefinicji. Mimo ogromnego wzrostu liczby i znaczenia aktorów niepaństwowych w stosunkach międzynarodowych, zasadniczym ich elementem pozostają nadal państwa. System Narodów Zjednoczonych powinien być zreformowany. Narody Zjednoczone, organizacje regionalne i integracyjne wymagają niezbędnych inicjatyw, by człowiek i jego potrzeby stanęły w centrum ich działalności. Znaczenie prawa międzynarodowego nie tylko nie maleje, lecz wzrasta. Istnieje bowiem ko- 
nieczność dostosowania porządku międzynarodowego do wyzwań i zagrożeń XXI wieku. Umowa międzynarodowa, regulacje międzynarodowe stają się niezbędne dla podjęcia wyzwań oraz zagrożeń, przed jakimi stoi społeczność międzynarodowa. Na prawo międzynarodowe oddziałują też procesy globalizacji, integracji i regionalizacji, w szczególności Unia Europejska. Nauka o stosunkach międzynarodowych nie może się prawidłowo rozwijać bez ścisłego związku z prawem międzynarodowym. Bez jego uwzględnienia staje się ona ułomna. Z kolei prawo międzynarodowe bez uwzględnienia stosunków międzynarodowych będzie dyscypliną dogmatyczną i scholastyczną.

\title{
INTERNATIONAL LAW AND THE DEVELOPMENT OF INTERNATIONAL RELATIONS
}

\begin{abstract}
International relations as an independent new discipline has been created by a process of separation from international law. The theory of international relations very rightly stressed that States' conduct neither can be fully determined nor can be viewed and analyzed exclusively by a prism of legal norms. Nevertheless, such approach can be criticized when it leads to underestimation, neglect or even rejection of any role for international law in international relations. In fact none international order can exist without principles, norms, procedures and institution based and created by international law. The end of the Cold War has created new opportunities for development and evolution of international law. One can observe profound changes concerning the notion of sovereignty, subjectivity, responsibility. The principle of non-intervention is replaced by the UN principle ,responsibility to protect”. Individuals responsible for international crimes due to the creation of many international tribunals are brought to criminal responsibility. An era of impunity comes to the end. Notion of international community and subjects of international law needs in $21^{\text {st }}$ century a redefinition. Despite great increase of numbers and importance of non-state actors States preserve their dominant position. United Nations system should be reformed. All intergovernmental, international organizations should put human beings of the center of their activities. The role and importance of international law in $21^{\text {st }}$ century is on rise. This is due to the need to meet new challenges and threats confronting international community. That why, international agreements and regulations are indispensible. International law is also under influence of new processes in particular globalization, regionalization and integration, including the European Union. Studies of international relations cannot be properly developed and brought adequate and just results without taking into account international law. By the same token international law without taking into account broadly understood international relations is threaten to be dogmatic and disconnected from reality.
\end{abstract}

